\title{
JARAK GENETIK POPULASI KUDA LOKAL SULAWESI UTARA BERDASARKAN ANALISIS MORFOLOGI DAN POLIMORFISME PROTEIN DARAH
}

\author{
Takaendengan B.J $^{1)}$, Ronny R Noor ${ }^{2)}$, Cece Sumantri ${ }^{2)}$, Sri Adiani ${ }^{1)}$ \\ ${ }^{1)}$ Fakultas Peternakan Universitas Sam Ratulangi, Manado 95115 \\ e-mail: juvarda@yahoo.com, sri adiani@yahoo.de \\ ${ }^{2)}$ Departemen Ilmu Produksi dan Teknologi Pemuliaan, Fakultas Peternakan, \\ Institut Pertanian Bogor, Bogor (e-mail: ronny noor@yahoo.com)
}

\begin{abstract}
ABSTRAK
Penelitian ini bertujuan untuk menentukan jarak genetik antar subpopulasi kuda lokal di Sulawesi Utara dengan menggunakan analisis morfologi dan polimorfisme protein darah. Subpopulasi kuda local yang diamati meliputi 505 ekor kuda dewasa yang terdiri dari 310 kuda jantan (stallion) dan 193 kuda betina (mare) dengan umur 2-7 tahun. Analisis morfologi digunakan untuk menentukan ukuran tubuh dan bobot badan, sedangkan analisis polimorfisme protein darah dilakukan untuk menduga keragaman genetic berdasarkan polimorfisme protein Albumin (Alb), post-albumin (PAlb), transferin (Tf), post-transferin 1 (PTf-1), post-transferin 2 (PTf-2), alfa-hemoglobin(Hba) dan beta-hemoglobin $(\mathrm{Hb} \beta)$. Analisis morfologi menunjukkan bahwa rata-rata ukuran badan dan bobot tubuh subpopulasi kuda Tomohon lebih tinggi $(\mathrm{p}<0.05)$ dibandingkan dengan subpopulasi di 3 daerah lainnya (Manado, Minahasa selatan dan Minahasa). Jarak genetik terdekat $(2,75)$ terdapat antara subpopulasi kuda Minahasa dan Minahasa Selatan, sedangakan jarak genetic terjauh $(9,02)$ terdapat antara subpopulasi kuda Tomohon dan Manado. Hasil kedua analisis ini menunjukkan bahwa subpopulasi kuda Tomohon mempunyai hubungan kekerabatan yang jauh dengan ketiga subpopulasi kuda Sulawesi Utara lainnya.
\end{abstract}

Kata kunci: jarak genetik, kuda, morfologi, polimorfisme protein darah

\section{DETERMINATION OF GENETIC DISTANCE ON NORTH SULAWESI NATIVE HORSES BASED ON ANALYSIS OF MORPHOLOGY AND BLOOD-PROTEIN POLYMORPHISM}

\begin{abstract}
This research aimed to determine genetic distance among subpopulations of North Sulawesi natice horses using analysis of morphology and blood protein polymorphism. The observed subpopulations of native horses included 505 mature horses 2-7 years old and consisted of 310 males (stallion) and 193 females (mare). Morphological analysis was used to determine the size and weight of body. Analysis of blood protein polymorphism was conducted to estimate genetic polymorphism of Albumin (Alb), Post Albumin (PAlb), Transferin (Tf), Post Transferin-1(PTf1), Post Transferin-2 (PTf2), alfa Hemoglobin ( $\mathrm{Hb} \alpha)$ and beta Hemoglobin $(\mathrm{Hb} \beta)$. Morphological analysis showed that average size and weight of body in subpopulation of Tomohon horses were bigger $(p<0,05)$ than 3 other ones (Manado, South Minahasa and Minahasa). The nearest genetic distance (viz. 2,75) was between Minahasa and South Minahasa horses, whereas the longest genetic distance was between Tomohon and Manado subpopulations. These analysis indicated that Tomohon horses bad far relationship to 3 other horse subpopulations ini North Sulawesi.
\end{abstract}

Keywords: genetic distance, horse, morphology, blood protein polymorphism

\section{PENDAHULUAN}

Populasi kuda di Indonesia berkisar 400 ribu ekor yang tersebar di beberapa daerah (BPS, 2010). Bangsa-bangsa kuda yang ada di Indonesia hingga saat ini umumnya merupakan hasil persilangan kudakuda lokal (Sandelwood pony) dengan bangsa kuda Arab atau kuda Thoroughbred, kuda asli Sumbawa, dan kuda-kuda asli Eropa (Equestrian Indonesia, 2008). Populasi kuda 
saat ini telah beradaptasi dengan lingkungannya serta mampu menghasilkan keturunan yang fertil, maka menurut Noor (2008) populasi tersebut telah terbukti mampu mengatasi cekaman lingkungan sehingga ternak seperti ini cocok untuk dikembangkan di Indonesia. Adaptasi terhadap perubahan genetik hanya terjadi apabila hewan baik populasi maupun individu mampu lolos dari faktor-faktor yang mengganggu seperti terjadinya mutasi, seleksi, migrasi (percampuran bangsa) dan penghanyutan genetik secara acak. (Liu, 1998; Lanari, et al. 2003), akan tetapi menurut Martodjo (2003), perubahan genetik dapat dimanfaatkan untuk mengetahui proses evolusi suatu populasi bangsa ternak dengan melihat jarak genetik suatu populasi.

Penelitian mengenai jarak genetik untuk populasi kuda di Indonesia masih belum banyak dilakukan. Salah satu metode dengan melihat adanya perbedaan fenotip dan genotip akibat adanya seleksi dan mutasi dapat juga dimanfaatkan untuk mengetahui jarak genetik adalah analisis keragaman (Komenes, 1999). Keragaman fenotip dapat diketahui dengan mengukur bagian-bagian tubuh atau morfometrik. (Freeland, 2005). Pengukuran ukuran tubuh digunakan untuk membedakan keragaman baik ukuran maupun bentuk tubuh terhadap populasi ternak berukuran besar seperti kuda (Dietl, Hoffmann \& Reinsch. 2005). Ukuran-ukuran tubuh sering dipakai secara rutin sebagai parameter pengganti dalam menduga bobot hidup ternak, sedangkan analisis keragaman dan korelasi banyak digunakan dalam mengkarakterisasi hubungan sifat-sifat fenotip dan genetik (Salako, 2006). Analisis komponen utama adalah bentuk modifikasi perhitungan yang dipakai saat karakterisasi secara fisik menunjukkan adanya hubungan yang erat antar parameter dengan berat hidup hewan (Salako dan Ngere, 2002).

Pendekatan ilmiah lainnya adalah dengan memanfaatkan teknologi molekuler yang berdasarkan penanda immunogenetik dan biokimia yang saat ini telah banyak dimanfaatkan dalam upaya pencatatan dan verifikasi keturunan dari kuda-kuda domestik. Hubungan antar populasi kuda dapat diungkap dengan memanfaatkan teknologi pengujian sampel sel darah merah dan polimorfisme protein darah (Bowling and
Ruvinsky, 2004). Analisis polimorfisme protein darah dengan menggunakan metode PAGE (Polyacrylamide Gel Electrophoresis) merupakan salah satu teknik yang sudah lama tetapi sering digunakan untuk mengidentifikasi enzim atau protein, yaitu metode yang sederhana dan relative murah dalam memisah-kan molekul kimia berdasarkan perbedaan ukuran, berat molekul, dan muatan listrik yang dikandung oleh makro molekul dengan menggunakan arus listrik. Protein merupakan salah satu bentuk makro molekul yang dihasilkan sel hidup yang berfungsi sebagai tempat penyimpanan informasi genetik (Rodwell, 1983).

Penelitian ini bertujuan untuk mendapatkan informasi keragaman fenotip dan jarak genetik dengan analisis morfologi dan polimorfisme protein darah beberapa populasi kuda lokal di Sulawesi Utara.

\section{METODOLOGI PENELITIAN}

\section{Waktu dan Tempat Penelitian}

Penelitian ini (pengukuran dan pengambilan sampel) dilaksanakan di propinsi Sulawesi Utara yaitu di 4 wilayah administrasi yaitu: Kabupaten Minahasa, Kabupaten Minahasa Selatan, Kota Tomohon dan Kota Manado, pada bulan April - Juni 2010. Analisis data dan laboratorium dilaksanakan di Laboratorium Pemuliaan dan Rekayasa Genetik, Fakultas Peternakan, Institut Pertanian Bogor, pada bulan Juli Desember 2010.

\section{Alat dan Bahan}

Alat

Peralatan yang digunakan adalah timbangan lapangan digital, pita meteran dan tongkat ukur (FHK stainless steel), alat tulis dan kamera digital SLR Nikon D70s 10 mega pixel. Alat untuk pengambilan sampel darah adalah jarum suntik Terumo (none) $5 \mathrm{ml}$, ice box, centrifuge tube $3 \mathrm{ml}$. Mikropipet P10, $\mathrm{P} 20$, beserta pipet tipnya, microtube eppendorf 1.5 dan 0.2, gelas ukur, erlenmeyer dan gelas piala. Peralatan elektronik untuk preparasi sampel adalah mikrosentrifus (Eppendorf Centrifuge 5415 C); vortex (Maxi Mix Thermolyne 37600 Mixer); waterbath (Grand Incubator); vacuum dryer (Centri Vap Concentrator, 
Labconco); magnetic stirrer ( $\mathrm{Mg}$ 78); electronic balance (AD HX 100) dan elektroforesis EP-155 (Advantec) pada arus 15-35mA dengan tegangan $150 \mathrm{~V}$ selama 1 jam 45 menit; voltage/current regulator.

\section{Bahan}

Populasi kuda yang dijadikan sampel penelitian adalah 505 ekor kuda yang sehat dan tidak bunting, terdiri dari 195 kuda betina dan 310 kuda jantan usia dari 2 sampai 7 tahun berdasarkan pendugaan gigi menurut metode Owen dan Bullock (2002). Sebanyak 148 sampel darah diambil untuk dianalisis protein dan sel darah merah dengan metode elektroforesis. Pewarnaan menggunakan Coomassie Brilliant Blue 2,5\%.

\section{Metode Penelitian}

Setiap individu kuda yang memenuhi kriteria umur dan kesehatan ditimbang bobot badan (BB) dan diukur ukuran tubuhnya yaitu: tinggi pundak (TP), panjang badan (PB), lebar dada (LbrD), dalam dada (DD), lingkar dada (LkD), tinggi pinggul (TPgl), panjang pinggul (PPgl), lebar pinggul (LPgl), panjang kepala (PK), panjang leher (PL) dan lebar kepala (LK). Beberapa titik anatomis dan prosedur pengukuran untuk ukuran tubuh tertentu mengalami sedikit perubahan berdasarkan petunjuk yang terdapat dalam Salako dan Ngere (2002). Hasil pengukuran dalam bentuk datasheet Excel (Microsoft Office, 2010) ditabulasi dan kemudian dianalisis secara deskriptif menggunakan program GLM, analisis komponen utama dengan program PCA dan analisis Cluster untuk menentukkan jarak Euclidean dari software komputer program SAS versi 9.0 (SAS Institut, 2000) serta berpedoman pada rumus menurut Steel dan Torrie (1995). Indeks morfologi dihitung dari nilai rataan ukuran-ukuran tubuh berdasarkan metode Alderson (1999).

Sampel darah disentrifugasi $(8000 \mathrm{rpm} /$ 30 menit). Plasma yang terbentuk kemudian dipindahkan ke tabung $1,5 \mathrm{ml}$ dan disimpan pada suhu $4{ }^{\circ} \mathrm{C}$. Elektroforesis protein plasma darah dilakukan menggunakan perangkat elektroforesis EP-155 (Advantec) dengan metode stacking poliakrilamid gel elektroforesis (PAGE) konsentrasi 5\% dan $3 \%$. Visualisasi pita protein menggunakan pewarnaan Coomassie Brilliant Blue 2,5\%, dan dicuci dengan methanol sampai pita kelihatan. Proses genotyping dilakukan dengan mensejajarkan pita-pita protein pada gel (Sambrook et al, 1989). Protein yang diamati meliputi Albumin (Alb), Post Albumin (PAlb), Transferin (Tf), Post Transferin-1 (PTf-1), dan Post Transferin-2 (PTf-2). Sedangkan sel darah merah yang diamati adalah Hemoglobin Alfa ( $\mathrm{HbA})$ dan Beta $(\mathrm{HbB})$. Frekuensi alel, heterozigositas, keseimbangan Hardy-Weinberg (HW) dan menggunakan rumus Nei dan Kumar (2000). Jarak genetik dan pohon kekerabatan dibuat dengan menggunakan software komputer program Mega versi 4 (Molecular Evolutionary Genetics Analysis) (Nei et al, 2007).

\section{HASIL DAN PEMBAHASAN}

\section{Kajian Morfometri}

Hasil analisis deskriptif yang ditampilkan pada Tabel 1, (Lampiran 1) secara umum menggambarkan populasi baik kuda jantan maupun betina memiliki ukuran tubuh yang hampir tidak berbeda $(\mathrm{P}<0.001)$, namun BB kuda betina lebih beragam dari jantan. Kuda jantan memiliki TP (122 \pm 9.8 $\mathrm{cm})$ lebih tinggi dari betina $(121 \pm 8.4 \mathrm{~cm})$, namun rataan TP keseluruhan menggambarkan kedekatan ukuran dari bangsa kuda poni di usia dewasa (Bowling and Ruvinsky, 2004). Ukuran TPgl yang cenderung sama dengan TP menjelaskan bahwa secara proporsional tubuh kuda berbentuk datar persegi saat berdiri yang mencirikan fungsi sebagai ternak tunggang atau tarik. Perbedaan topografi wilayah pada Tabel 2 (Lampiran 2), menunjukkan bahwa populasi kuda di kota Manado dan Kabupaten Minsel memiliki bobot tubuh yang lebih ringan dari populasi di kota Tomohon dan kabupaten Minahasa hal ini diduga lebih dipengaruhi oleh beberapa faktor lingkungan, misalnya pakan (ketersediaan rumput), suhu yang panas (tepi pantai) dan kondisi peternak (sosial-ekonomi). Nilai koefisien keragaman (cv) berkisar dari rendah sampai sedang pada beberapa parameter ukuran tubuh menjelaskan adanya seleksi secara tidak langsung pada kuda-kuda lokal di Minahasa dan secara genetik mengarah pada pembentukkan bangsa kuda lokal yang baru. Kesamaan ukuran tubuh pada jantan dan betina juga pernah dilaporkan pada bangsa 
ternak besar lainnya seperti ternak sapi (Gilbert, Bailey \& Shannon, 1993).

Ukuran dan bobot badan populasi kuda di kota Tomohon memiliki perbedaan yang nyata dibandingkan populasi kuda di wilayah lainnya. Hal itu menandakan bahwa kuda lokal di Tomohon secara fenotip berbeda dengan kuda-kuda di tiga daerah lainnya. Pengamatan visual dilapangan dan hasil analisis data menunjukkan bahwa populasi kuda di kota Tomohon lebih didominasi oleh ukuran dan tipe bangsa kuda thoroughbred yang banyak dipelihara untuk pacuan. Hal ini diperkuat dengan hasil analisis indeks morfologi pada Tabel 2 (Lampiran 2) dimana WI dan CI pada populasi kuda di Tomohon memiliki bobot paling berat dan secara kumulatif menggambarkan bahwa postur tubuh kuda di Tomohon lebih besar dari populasi kuda lainnya. Hasil perhitungan indeks yang didasarkan dari pengukuran yang saling berkaitan erat pada bagian-bagian tubuh ternak menggambarkan kestabilan bentuk dari suatu bangsa ternak. Oleh sebab berdasarkan nilai CI, populasi kuda di Tomohon memiliki kaki-kaki dan tubuh yang lebih panjang yang lebih mencirikan kuda pacuan. Sedangkan populasi kuda di Manado dan Minahasa Selatan memiliki proporsi tubuh yang cenderung sebagai ternak kerja atau mild draught horse.

Secara keseluruhan analisis indeks morfometrik menjelaskan bahwa kuda jantan memiliki dimensi lebih berat, lebih tinggi, lebih lebar, lebih panjang dan bagian depan lebih kokoh. Analisis komponen utama (Tabel 3) pada Lampiran 2 yang menunjukkan bahwa pada ternak jantan selain ukuran TP dan TPgl terdapat variable PB, LD dan DD menguatkan hasil pengukuran morfometrik. Besar nilai korelasi ke lima komponen diatas dengan bobot badan sangat tinggi yaitu: $70 \mathrm{~s} / \mathrm{d} 90 \%$. Sedangkan kuda betina lebih menonjol pada dimensi bagian belakang, mulai dari bagian punggung ke arah pinggul. Nilai WS yang lebih besar dari kuda jantan mengindikasi bahwa kuda betina adalah hewan yang ramping didukung oleh hasil analisis komponen utama yang menunjukkan bahwa faktor pertama yang menonjol pada ternak betina selain TP, TPgl adalah komponen PP dan LPgl dengan nilai korelasi: 77 - $87 \%$.
Sebagai faktor penentu fungsionalitas, maka WS dan LI merupakan parameter utama dalam menduga dimensi kesetimbangan (balance). Salako (2006) menyatakan bahwa bentuk tubuh (tipe, struktur dan proporsi) sangat baik untuk dimanfaatkan pada hewan atau ternak yang telah berproduksi. Ukuran tubuh yang dapat dijadikan patokan pengukuran pada populasi kuda lokal baik jantan maupun betina berdasarkan hasil analisis adalah komponen TPgl, TP, dan LD. Faktor pertama ini cenderung menggambarkan pada komponen utama ukuran tubuh. Hal yang sama ditemukan untuk pengukuran komponen utama dari sapi hitam Jepang pada bangsa sapi yang dilaporkan oleh Fumio dkk (1982) dan Hammock, S.P. dan R.R. Shrode (1986) . Karacaoren, B. dan H.N. Kadarmideen (2008) dan Sadek, M.H. dkk (2006) juga dalam penelitiannya menjelaskan bahwa faktor pertama dari analisis komponen utama memiliki keragaman yang paling tinggi yaitu antara $54.8-70.0$ persen.

Faktor kedua dan ketiga menjelaskan komponen utama yang berkaitan dengan bentuk tubuh. Hasil penelitian menunjukkan bahwa komponen yang dapat menjadi patokan dalam bentuk kuda lokal adalah komponen PK kuda $(47-49 \mathrm{~cm})$ dengan nilai korelasi fenotip sebesar 48-64\%. Konformasi tubuh ternak adalah sifat-sifat yang baik untuk dijadikan dasar dalam melakukan seleksi dan evaluasi genetik ternak. Seleksi berdasarkan kelompok peubah dengan memanfaatkan faktor-faktor dalam kedua komponen ini lebih mudah untuk dipakai dibandingkan menggunakan sifat-sifat terpisah Salako (2006).

\section{Kajian Genetik}

Terdapat 7 lokus yang dikaji yaitu Post Transferin-1(PTf-1),Post Transferin-2 (PTf2), Transferin (Tf), Post Albumin (PAlb), Albumin (Alb) ,Hemoglobin alfa (HbA) dan Hemoglobin beta (HbB). Dari Gambar 4 dan 5 (Lampiran 4) terlihat adanya keragaman pola pita protein berdasarkan perbedaan bentuk dan jarak pada lokus Tf, PAlb, Alb dan HbA memperlihatkan adanya 2 pita. Sehingga hal ini menunjukkan adanya variasi lokus populasi kuda. Semetara lokus lain hanya nampak pola protein pita tunggal. Hasil analisis frekuensi alel pada kuda lokal 
Sulawesi Utara berdasarkan lokus Alb, PAlb, Tf, PTf-1, PTf-2 disajikan pada Tabel 4 (Lampiran 4) menujukkan lokus Alb alel A memiliki frekuensi tertinggi yaitu sebesar 0,85 dan terendah pada alel B sebesar 0,15 di populasi Tomohon. Frekuensi alel tertinggi pada lokus PAlb alel B sebesar 0,625 di daerah Manado dan terendah pada alel C sebesar 0,00. Frekuensi alel tertinggi pada lokus Tf yaitu alel B sebesar 0.731 dan terendah pada alel $\mathrm{C}$ sebesar 0,038 di daerah Amurang. Frekuensi alel tertinggi pada lokus PTf-1 dan PTf-2 masing-masing pada alel A sebesar 1,000 dan terendah pada alel B sebesar 0,000 untuk semua populasi.

Variabilitas genetik kuda lokal di Sulawesi Utara (Tabel 5) pada Lampiran 4 menunjukkan bahwa lokus PAlb dari empat populasi memiliki nilai heterozigositas tertinggi yaitu sebesar $100 \%$ yang mencerminkan adanya polimorfik yang tinggi pada populasi kuda di kota Tomohon. Nilai heterozigositas tertinggi pada lokus Transferin sebesar $90 \%$ pada populasi Tomohon. Nilai heterozigositas tertinggi pada lokus Alb sebesar 50\% terdapat pada populasi kuda di Manado. Lokus yang lain tidak menunjukkan adanya variasi yaitu lokus PTf-1 dan PTf-2 semuanya menunjukkan genotipe homozigot yang sama yaitu genotipe AA. Perbedaan keragaman genetik dapat disebabkan oleh perbedaan lingkungan yang berbeda secara topografi dan juga adanya perbedaan sistem pemeliharaan dari peternak di keempat lokasi. Kota Tomohon diduga telah melakukan pola pemeliharaan dan sistem persilangan yang diawasi.

\section{Analisis Jarak Genetik}

Analisis cluster ditujukkan untuk mengelompokkan sejumlah individu ke dalam kelompok-kelompok berdasarkan derajat kemiripan yang paling dekat. Berdasarkan metode cluster observation dengan metode average linkage (pautan rataan) jarak Euclidean diperoleh gambaran berupa diagram pohon dari data morfologi ukuran tubuh dan bobot badan populasi kuda di Sulawesi Utara pada kedua jenis kelamin seperti tertera pada Gambar 1 - 3 (Lampiran 3). Secara umum populasi keempat daerah terbagai dalam 3 kelompok besar, berdasarkan parameter ukuran tubuh dan indeks morfologi, dimana kelompok pertama adalah populasi kuda di kota Manado dan kabupaten Minsel. Keduanya tergabung dalam kelompok yang lebih jauh yaitu populasi kuda di kabupaten Minahasa. Hubungan terjauh terdapat pada kelompok kuda di kota Tomohon.

Perbedaan jarak genetik terjadi perubahan dengan parameter indeks morfometrik pada kuda jantan, dimana selain kota Tomohon, kelompok terdekat pertama adalah populasi di kedua kabupaten yaitu Minahasa dan Minsel kemudian dengan jarak lebih jauh kota Manado. Hasil ini lebih mirip dengan hasil pengelompokkan berdasarkan analisis genotip protein darah yang menunjukkan populasi kuda di kabupaten Minsel memiliki hubungan kekerabatan yang dekat dengan populasi kuda di kabupaten Minahasa dan populasi kuda di Tomohon memiliki hubungan kekerabatan yang jauh dengan ketiga populasi kuda lainnya. Hal ini dikarenakan kota Tomohon yang merupakan daerah dataran tinggi (500 dpl) dengan keadaan daerah perbukitan telah melakukan seleksi yang bertujuan untuk mendapatkan suatu populasi kuda dengan postur tubuh yang besar dan dapat disesuaikan dengan kondisi geografis kota Tomohon. Perbedaan jarak genetik tersebut memberikan arti penting untuk pemanfaatan kuda lokal di Sulawesi Utara. Berdasarkan dendogram morfologis dan genotype populasi di empat wilayah di Sulawesi Utara di duga berasal dari dua populasi yang berbeda.

\section{KESIMPULAN DAN SARAN}

\section{Kesimpulan}

Terdapat variasi morfologi dan polimorfis protein darah pada lokus Alb, PAlb, Tf dan HbA antar individu dalam satu populasi. Sehingga dapat dikatakan bahwa terdapat polimorfisme genetik kuda lokal di empat populasi di Sulawesi Utara. Lokus lainnya bersifat monomorfik.

Variasi morfologi kuantitatif meliputi bobot badan dan variable ukuran tubuh dari seluruh populasi kuda yang tersebar di empat wilayah serta terdapat dimorfisme seksual dimana antar kuda jantan dan betina terdapat komponen pembeda yang jelas.

Dari hasil analisis clustering pengelompokkan individu berdasarkan ciri morfometrik, indeks dan genotipe diketahui terdapat kesamaan antar indeks morfologi 
pada populasi kuda jantan dengan genotype protein darah.

\section{Saran}

Indeks kumulatif menurut metode Alderson merupakan alat ukur paling baik untuk mendapatkan nilai fungsional dari individu atau populasi ternak yang dipelihara, akan tetapi diperlukan sekurang-kurangnya lima peubah pada indeks kumulatif agar dapat dipakai sebagai indikator untuk menilai kegunaan dari populasi kuda di Minahasa.

Terdapat korelasi yang tinggi dan positip antara peningkatan terhadap beberapa ukuran tubuh dengan bobot badan, yang menjadikan faktor tersebut bermanfaat sebagai bahan pertimbangan dan pengambilan keputusan dalam satu rancangan program pemuliaan dan seleksi dengan hanya memakai pengukuran yang sederhana dan mudah.

Hasil ini membuktikan dimasa yang akan datang pengukuran dapat dilakukan hanya dengan mengukur ukuran-ukuran tubuh yang berkaitan secara linier untuk menduga sifat-sifat tertentu dibandingkan dengan memanfaatkan timbangan dan alat ukur yang lain yang tidak praktis dan rumit.

\section{DAFTAR PUSTAKA}

Alderson, G.L.H. 1999. The development of a system of linear measurements to provide an assessment of type and fuction of beef cattle. AGRI, 25:45-55.

Badan Pusat Statistik. 2010. Statistik Peternakan. BPS. Jakarta. http://www.bps.go.id/ [7 $\quad$ February 2010].

Bowling, A.T., and A. Ruvinsky. 2004. The Genetics of The Horse, $1^{\text {st }}$ ed. CAB International. Wallingford. UK.

Equestrian Indonesia, 2008. Grading up kuda lokal dengan thoroughbred. www.equestrian-indonesia.org/ [19 April 2009].

Freeland, J.R. 2005. Molecular Ecology. John Wiley and Sons, Ltd. England.
Gilbert, R.P., D.R.C. Bailey and N.H. Shannon. 1993. Linear body measurements of cattle before and after 20 years of selection for post-weaning gain when fed two different diets. $J$ Anim Sci. 71:1712-1720.

Komenes, P.A. 1999. Alfa-casein and betalactoglobulin and growth hormone alleles frequencies and genetik distances in Nelore, GYR, Guzera, Caracu, Charolais, Canchim and Santa Getrudis cattles. Gen Mol Biol 22:539-541.

Liu, B.H. 1998. Statistical Genomic; linkage, mapping and QTL analysis. New York: CRC Press.

Martojo, H. 2003. Indigenous Bali Cattle: The Best Suited Cattle Breed for Sustainable Small Farms in Indonesia. Laboratory of Animal Breeding and Genetics. Faculty of Animal Science. Bogor: IPB.

Nei, M., and S. Kumar. 2000. Molecular Evaluation and Phylogenetics. Oxford University Press. New York.

Nei, M., S. Kumar, K. Tamura. and J. Dudley. 2007. Molecular Evolutionary Genetics Analysis. Versi ke-4. Center for Evolutionary Fuctional Genomics. Biodesign Institute. Ariszona State University. Arizona.

Noor, R.R. 2008. Genetika Ternak. Edisi ke4. Penebar Swadaya, Jakarta.

Owen, R., \& J. Bullock. 2002. Complete Book of The Horse and Rider. Hamlyn Pub. Ltd. England.

Salako, A.E., and L. O Ngere. 2002. Application of multifactorial discriminant analysis in the morphometric structural differentiation of the WAD and Yankasa sheep in the humid southwest Nigeria. Nig. J. Anim. Prod. 29(2):163-7.

Sambrook, J., E.F. Fritsch \& T. Maniastis. 1989. Molecular Cloning. Di dalam: $A$ Laboratory Manual. Ed ke-2. Cold Spring Harbor Laboratory Press. 


\section{Lampiran 1.}

Tabel 1. Deskripsi morfometrik kuda lokal berdasarkan kelompok jenis kelamin dan lokasi.

\begin{tabular}{|c|c|c|c|c|c|c|c|c|c|c|c|c|c|c|c|c|c|c|}
\hline \multirow{3}{*}{$\begin{array}{l}\text { Sifat (cm) } \\
\text { BB }(\mathbf{k g})\end{array}$} & \multicolumn{6}{|c|}{ Jenis Kelamin } & \multicolumn{12}{|c|}{ Lokasi } \\
\hline & \multicolumn{3}{|c|}{$\begin{array}{c}\text { Jantan }(\mathrm{N}=310) \\
(\text { rataan/sd/cv) }\end{array}$} & \multicolumn{3}{|c|}{$\begin{array}{c}\text { Betina(N=195) } \\
\text { (rataan/sd/cv) }\end{array}$} & \multicolumn{3}{|c|}{$\begin{array}{c}\text { Manado(N=57) } \\
(\text { rataan/sd/cv) }\end{array}$} & \multicolumn{3}{|c|}{$\begin{array}{c}\text { Minahasa }(\mathrm{N}=374) \\
(\text { rataan/sd/cv) }\end{array}$} & \multicolumn{3}{|c|}{$\begin{array}{c}\text { Minsel(N=33) } \\
(\text { rataan/sd/cv) }\end{array}$} & \multicolumn{3}{|c|}{$\begin{array}{c}\text { Tomohon }(\mathrm{N}=41) \\
(\text { rataan } / \mathrm{sd} / \mathrm{cv})\end{array}$} \\
\hline & 239 & 51.7 & 21.6 & 239 & 46.4 & 19.4 & 201 & 40.4 & 20.1 & 243 & 45.6 & 18.8 & 191 & 20.4 & 10.7 & 292 & 49.0 & 20.1 \\
\hline LD & 144 & 11.1 & 7.7 & 145 & 12.2 & 8.4 & 137 & 8.7 & 6.4 & 146 & 11.2 & 7.7 & 137 & 4.9 & 3.6 & 156 & 9.8 & 6.4 \\
\hline LbrD & 28 & 3.4 & 12.0 & 28 & 4.3 & 15.4 & 26 & 2.5 & 10.5 & 28 & 3.8 & 13.5 & 27 & 1.7 & 6.4 & 31 & 3.0 & 10.5 \\
\hline DD & 54 & 5.6 & 10.3 & 54 & 5.2 & 9.5 & 51 & 4.0 & 7.8 & 54 & 5.1 & 9.4 & 52 & 3.0 & 5.7 & 61 & 5.4 & 7.8 \\
\hline TP & 122 & 9.8 & 8.0 & 121 & 8.4 & 6.9 & 117 & 6.1 & 5.3 & 122 & 8.6 & 7.0 & 116 & 4.6 & 3.9 & 134 & 10.1 & 5.3 \\
\hline TPgl & 123 & 9.8 & 7.9 & 123 & 8.5 & 6.8 & 118 & 6.5 & 5.5 & 124 & 8.8 & 7.1 & 118 & 4.6 & 3.9 & 134 & 10.4 & 5.5 \\
\hline LPgl & 39 & 4.7 & 12.0 & 41 & 3.6 & 8.8 & 34 & 5.2 & 15.2 & 40 & 3.6 & 8.8 & 39 & 2.0 & 5.3 & 43 & 3.9 & 15.2 \\
\hline PB & 117 & 6.5 & 6.7 & 119 & 5.7 & 5.8 & 112 & 5.9 & 6.7 & 118 & 5.9 & 6.2 & 115 & 3.8 & 4.2 & 122 & 3.9 & 6.7 \\
\hline PP & 39 & 3.8 & 9.7 & 40 & 3.1 & 7.7 & 37 & 2.9 & 7.8 & 40 & 3.5 & 8.7 & 38 & 1.9 & 4.9 & 43 & 3.4 & 7.8 \\
\hline PL & 54 & 5.5 & 10.0 & 54 & 5.3 & 9.7 & 54 & 4.3 & 7.9 & 54 & 5.4 & 9.9 & 51 & 4.5 & 8.9 & 58 & 5.5 & 7.9 \\
\hline LK & 20 & 1.0 & 5.1 & 20 & 1.1 & 5.5 & 20 & 1.1 & 5.7 & 20 & 1.0 & 5.0 & 19 & 0.8 & 3.9 & 21 & 0.9 & 5.7 \\
\hline PK & 47 & 3.4 & 7.2 & 49 & 3.6 & 7.4 & 47 & 3.1 & 6.5 & 48 & 3.7 & 7.6 & 45 & 1.8 & 4.1 & 49 & 2.2 & 6.5 \\
\hline
\end{tabular}

Semua koefisien nyata tidak berbeda $(\mathrm{P}<0.01)$; sd = standar deviasi; cv = coefficient of variation $(\%)$; $\mathrm{BB}=\mathrm{Bobot}$ badan $(\mathrm{kg}) ; \mathrm{LD}=\mathrm{Lingkar}$ dada $(\mathrm{cm}) ; \mathrm{LbrD}=\mathrm{Lebar}$ dada(cm); $\mathrm{DD}=$ Dalam dada $(\mathrm{cm})$; TP=Tinggi pundak $(\mathrm{cm}) ; \mathrm{TPgl}=$ Tinggi pinggul $(\mathrm{cm}) ; \mathrm{LPgl}=\mathrm{Lebar}$ pinggul $(\mathrm{cm}) ; \mathrm{PB}=\mathrm{Panjang}$ badan $(\mathrm{cm}) ; \mathrm{PP}=\mathrm{Panjang}$ paha $(\mathrm{cm}) ; \mathrm{PL}=\mathrm{Panjang}$ leher $(\mathrm{cm})$; LK=Lebar kepala $(\mathrm{cm})$ dan PK=Panjang kepala $(\mathrm{cm})$ 
Lampiran 2.

Tabel 2. Morphological indices of matured Minahasa local horse by sex and region.

\begin{tabular}{|c|c|c|c|c|c|c|c|c|c|c|c|c|c|c|c|c|c|c|}
\hline \multirow{3}{*}{$\begin{array}{l}\text { Indeks } \\
\text { WI }\end{array}$} & \multicolumn{6}{|c|}{ Jenis Kelamin } & \multicolumn{12}{|c|}{ Lokasi } \\
\hline & \multicolumn{3}{|c|}{$\begin{array}{c}\text { Jantan }(\mathrm{N}=310) \\
(\text { rataan/sd/cv) }\end{array}$} & \multicolumn{3}{|c|}{$\begin{array}{c}\text { Betina }(\mathrm{N}=195) \\
\text { (rataan/sd/cv) }\end{array}$} & \multicolumn{3}{|c|}{$\begin{array}{c}\text { Manado(N=57) } \\
(\text { rataan/sd/cv) }\end{array}$} & \multicolumn{3}{|c|}{$\begin{array}{c}\text { Minahasa(N=374) } \\
(\text { rataan/sd/cv) }\end{array}$} & \multicolumn{3}{|c|}{$\begin{array}{c}\text { Minsel(N=33) } \\
(\text { rataan/sd/cv) }\end{array}$} & \multicolumn{3}{|c|}{$\begin{array}{c}\text { Tomohon }(\mathrm{N}=41) \\
(\text { rataan } / \mathrm{sd} / \mathrm{cv})\end{array}$} \\
\hline & $57 \mathrm{E} 4$ & $12 \mathrm{E} 4$ & 22.26 & 40E4 & 7.4E4 & 18.73 & $46 \mathrm{E} 4$ & 9.7E40 & 21.16 & $59 \mathrm{E} 4$ & $10 \mathrm{E} 4$ & 18.28 & 33E4 & $3.8 \mathrm{E} 4$ & 11.30 & $72 \mathrm{E} 4$ & $13 \mathrm{E} 4$ & 17.67 \\
\hline HS & 1.00 & 0.02 & 2.30 & 0.98 & 0.02 & 2.14 & 0.99 & .22 & 1.78 & 0.99 & 0.02 & 2.44 & 0.99 & 0.02 & 2.10 & 1.01 & 0.02 & 1.82 \\
\hline WS & 1.40 & 0.15 & 10.94 & 1.46 & 0.13 & 9.06 & 1.33 & 0.19 & 14.32 & 1.44 & 0.14 & 9.98 & 1.45 & 0.08 & 5.78 & 1.41 & 0.12 & 8.63 \\
\hline LI & 0.96 & 0.05 & 4.84 & 0.65 & 0.03 & 5.40 & 0.96 & 0.04 & 3.85 & 0.97 & 0.05 & 4.72 & 0.65 & 0.03 & 3.85 & 0.91 & 0.04 & 4.62 \\
\hline DI & 0.44 & 0.02 & 4.04 & 0.45 & 0.02 & 4.75 & 0.43 & 0.02 & 4.18 & 0.44 & 0.02 & 4.38 & 0.45 & 0.02 & 3.56 & 0.46 & 0.02 & 3.44 \\
\hline $\mathrm{Fl}$ & 68.40 & 4.98 & 7.28 & 67.01 & 4.63 & 6.90 & 65.91 & 3.35 & 5.08 & 67.92 & 4.64 & 6.83 & 64.03 & 3.05 & 4.76 & 73.18 & 5.53 & 7.56 \\
\hline Balance & 1.02 & 0.14 & 13.35 & 1.09 & 0.12 & 11.33 & 0.96 & 0.15 & 15.72 & 1.06 & 0.13 & 12.70 & 1.07 & 0.10 & 9.21 & 0.99 & 0.09 & 9.20 \\
\hline $\mathrm{CI}$ & 2.97 & 0.25 & 8.52 & 2.74 & 0.23 & 8.54 & 2.77 & 0.24 & 8.75 & 3.05 & 0.24 & 8.78 & 2.52 & 0.15 & 5.76 & 3.12 & 0.19 & 6.37 \\
\hline
\end{tabular}

Semua koefisien nyata tidak berbeda $(\mathrm{P}<0.01) ; \mathrm{sd}=$ standar deviasi; $\mathrm{cv}=$ coefficient of variation $(\%) ; . \mathrm{WI}=$ weight index $; \mathrm{HS}=$ height slope $; \mathrm{WS}=$ width slope $; \mathrm{LI}=$ length

index; $\mathrm{DI}=$ depth index $; \mathrm{Fl}=$ foreleg index $; \mathrm{CI}=$ coefficient index.

Tabel 3. Nilai Eigen dan pembagian ragam total ketiga faktor pengukuran tubuh kuda lokal Minahasa

\begin{tabular}{|c|c|c|c|c|c|c|c|c|c|c|c|c|c|c|c|c|c|c|}
\hline \multirow{3}{*}{$\mathrm{N}$} & \multicolumn{6}{|c|}{ Jenis Kelamin } & \multicolumn{12}{|c|}{ Lokasi } \\
\hline & \multicolumn{3}{|c|}{ Jantan $(\mathrm{N}=310)$} & \multicolumn{3}{|c|}{ Betina $(\mathrm{N}=195)$} & \multicolumn{3}{|c|}{ Manado $(\mathrm{N}=57)$} & \multicolumn{3}{|c|}{ Minahasa $(\mathrm{N}=374)$} & \multicolumn{3}{|c|}{ Minsel(N=33) } & \multicolumn{3}{|c|}{ Tomohon(N=41) } \\
\hline & $I$ & $i i$ & $i i i$ & $i$ & $i i$ & $i i i$ & $i$ & $i i$ & $i i i$ & $I$ & $i i$ & $i i i$ & $i$ & $i i$ & $i i i$ & $i$ & $i i$ & $i i i$ \\
\hline $\mathrm{I}$ & $\begin{array}{l}\text { TP,TPgl } \\
\text { PB, LD, } \\
\text { DD }\end{array}$ & 66.1 & 7.3 & $\begin{array}{l}\text { TP, Tpgl } \\
\text { PP, LPgl }\end{array}$ & 61.0 & 6.7 & $\begin{array}{l}\text { TP,TPgl } \\
\text { PB, LD } \\
\text { DD, PP }\end{array}$ & 55.5 & 6.1 & $\begin{array}{l}\text { TP,TPgl } \\
\text { PB, LD } \\
\text { LPgl, }\end{array}$ & 60.1 & 6.7 & $\begin{array}{l}\text { TPgl } \\
\text { PB,LD } \\
\text { PP, }\end{array}$ & 53.5 & 5.9 & $\begin{array}{l}\text { TP, TPgl } \\
\text { LD, DD } \\
\text { PP, }\end{array}$ & 69.1 & 7.6 \\
\hline II & PL,PK & 8.2 & 0.9 & LbrD & 11.3 & 1.2 & PL, PK & 13.1 & 1.4 & LbrD & 9.5 & 1.0 & $\mathrm{DD}, \mathrm{TP}$ & 11.5 & 1.3 & PL,PK & 8.4 & 0.9 \\
\hline III & LK & 5.9 & 0.7 & PK, LK & 7.1 & 0.8 & LK & 7.6 & 0.8 & PK, LK & 6.7 & 0.7 & PL, PK & 8.3 & 0.9 & LK,LbrD & 7.1 & 0.8 \\
\hline
\end{tabular}

Ket: N=faktor; i=komponen; ii=keragaman(\%); iii=nilai Eigen. BB=Bobot badan(kg); LD=Lingkar dada(cm); LbrD=Lebar dada(cm); DD= Dalam dada (cm); TP=Tinggi pundak $(\mathrm{cm})$; TPgl=Tinggi pinggul $(\mathrm{cm})$; LPgl=Lebar pinggul $(\mathrm{cm})$; PB=Panjang badan $(\mathrm{cm}) ;$ PP=Panjang paha( $\mathrm{cm})$; PL=Panjang leher(cm); LK=Lebar kepala $(\mathrm{cm})$ dan $\mathrm{PK}=$ Panjang kepala $(\mathrm{cm})$. 


\section{Lampiran 3.}

\begin{tabular}{|ccccccc|}
\hline $\begin{array}{c}\text { C A S E } \\
0\end{array}$ & 5 & 10 & 15 & 20 & 2 \\
5 & & & & & & \\
\hline
\end{tabular}

Gambar 1a. Dendogram jarak euklidean tingkat kesamaan individu berdasarkan parameter ukuran tubuh kuda betina.

\begin{tabular}{|c|c|c|c|c|c|}
\hline $\begin{array}{llll}C & A & S & E \\
0 & & & \end{array}$ & $25 \quad 0$ & 5 & 10 & 15 & 2 \\
\hline $\begin{array}{r}\text { Label } \\
---+---\end{array}$ & $\begin{array}{r}\text { Num } \\
------+\end{array}$ & +------- & --- & ---- & \\
\hline
\end{tabular}

Gambar 1b. Dendogram jarak euklidean tingkat kesamaan individu berdasarkan parameter indeks tubuh kuda betina.

\begin{tabular}{|c|c|c|c|c|c|}
\hline$C A S E$ & 0 & 5 & 10 & 15 & 20 \\
\hline Label & Num & +------ & -- & - & -- \\
\hline
\end{tabular}

Gambar 2a. Dendogram jarak euklidean tingkat kesamaan individu berdasarkan parameter ukuran tubuh kuda jantan.

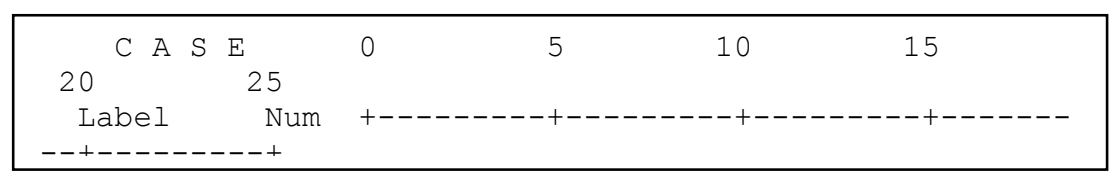

Dendrogram using Average Linkage (Between Groups Male)

Rescaled Distance Cluster Combine

Gambar 2b. Dendogram jarak euklidean tingkat kesamaan individu berdasarkan parameter indeks tubuh kuda jantan.

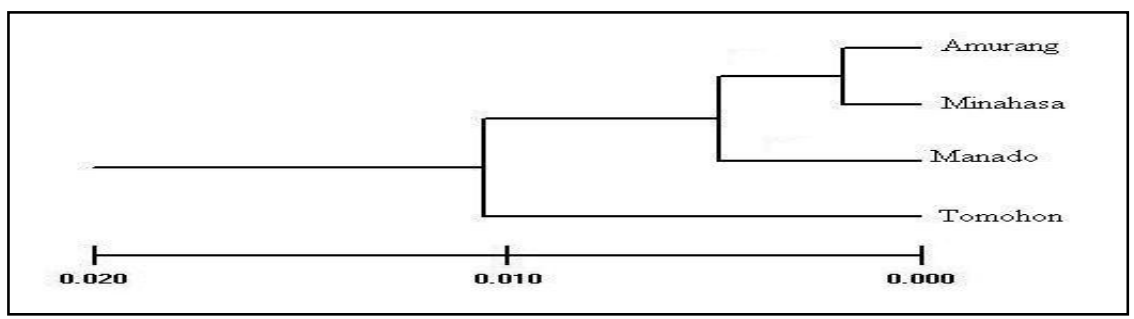

Gambar 3. Dendrogram Pohon Genetik berdasarkan Metode UPGMA

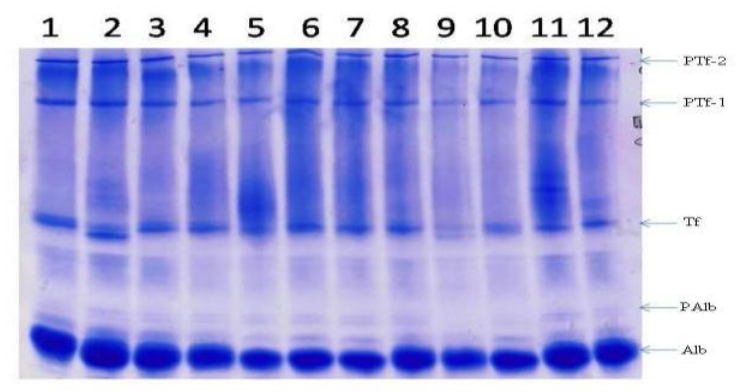

Gambar 4. Contoh Pola Pita Alb, PAlb, Tf, PTf-1, dan PTf-2 berdasarkan Teknik PAGE 


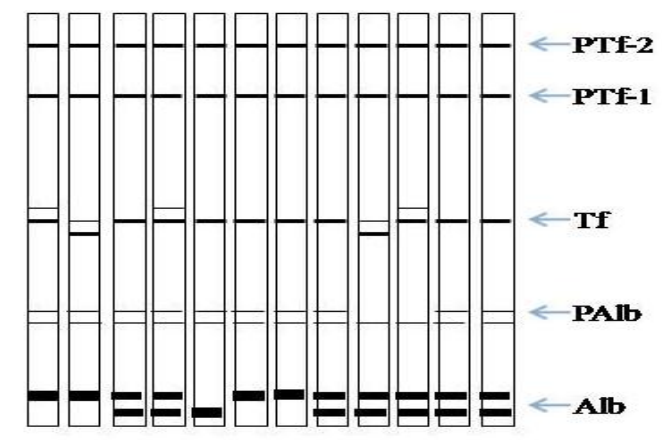

Gambar 5. Rekonstruksi Pola Pita PTf-2,PTf-1, Tf, PAlb, Alb berdasarkan Teknik PAGE

Lampiran 4.

Tabel 4. Frekuensi Alel Kuda Lokal Sulawesi Utara

\begin{tabular}{|c|c|c|c|c|c|c|c|c|c|c|c|c|}
\hline \multirow[t]{2}{*}{ Populasi } & \multicolumn{2}{|c|}{ Albumin } & \multicolumn{3}{|c|}{ Post Albumin } & \multicolumn{3}{|c|}{ Transferin } & \multicolumn{2}{|c|}{$\begin{array}{c}\text { PostTransferin- } \\
1\end{array}$} & \multicolumn{2}{|c|}{$\begin{array}{l}\text { PostTransferin- } \\
2\end{array}$} \\
\hline & $\mathrm{A}$ & $\mathrm{B}$ & $\mathrm{A}$ & $\mathrm{B}$ & $\mathrm{C}$ & $\mathrm{A}$ & $\mathrm{B}$ & $\mathrm{C}$ & $\mathrm{A}$ & $\mathrm{B}$ & $\mathrm{A}$ & $\mathrm{B}$ \\
\hline Tomohon & 0.85 & 0.15 & 0.50 & 0.50 & 0,00 & 0.25 & 0.55 & 0.20 & 1,0 & 0,0 & 1,0 & 0,0 \\
\hline Manado & 0.68 & 0.32 & 0.38 & 0.63 & 0,00 & 0.23 & 0.66 & 0.11 & 1,0 & 0,0 & 1,0 & 0,0 \\
\hline Amurang & 0.7 & 0.27 & 0.50 & 0.50 & 0,00 & 0.23 & 0.73 & 0.04 & 1,0 & 0,0 & 1,0 & 0,0 \\
\hline Minahasa & 0.7 & 0.24 & 0.46 & 0.52 & 0.02 & 0.26 & 0.65 & 0.09 & 1,0 & 0,0 & 1,0 & 0,0 \\
\hline
\end{tabular}

Tabel 5. Heterozigositas Kuda Lokal Sulawesi Utara

\begin{tabular}{lccccc} 
Populasi & Alb & PAlb & Tf & PTf-1 & PTf-2 \\
\hline Tomohon & 0,10 & 1,00 & 0,90 & 0,00 & 0,00 \\
Manado & 0,50 & 0,75 & 0,68 & 0,00 & 0,00 \\
Amurang & 0,23 & 1,00 & 0,54 & 0,00 & 0,00 \\
Minahasa & 0,30 & 0,83 & 0,69 & 0,00 & 0,00 \\
Total & 0,34 & 0,85 & 0,69 & 0,00 & 0,00 \\
\hline
\end{tabular}

